\title{
急流中小都市河川が貫流する密集市街地での 浸水・排水プロセスのシミュレーション SIMULATIONS OF URBAN INUNDATION AND DRAINAGE PROCESSES IN A HILLY URBAN AREA
}

\author{
秋山 壽一郎 1 ・重枝 未玲 2 ・津﨑 周平 3 ・重岡 広美 3 \\ Juichiro AKIYAMA, Mirei SHIGE-EDA, Shuhei TSUZAKI and Hiromi SHIGEOKA \\ 1フェロー会員 Ph. D. 九州工業大学教授 工学部建設社会工学科（†804-8550北九州市戸畑区仙水町1-1） \\ 2正会員 博士 (工学) 九州工業大学助教授 工学部建設社会工学科（同上） \\ 3学生会員 九州工業大学大学院 工学研究科建設社会工学専攻（同上）
}

\begin{abstract}
The inundation and drainage processes in a hilly urban area where a steep urban river, with complicated geometry and hydraulic structures, flows through are investigated by the $2 \mathrm{D}$ inundation model, which comprises the finitevolume method with unstructured grid and flux-difference splitting(FDS). The flood flow in the river and inundation flow in the urban district are solved simultaneously by the model in order to evaluate overflow discharges from the river as precisely as possible. The inundation and drainage processes along with the roles of the overflow discharges, sewerage system and overland flows due to rainfall in the inundation and drainage processes of the district are identified for measures of the mitigation against flood disasters.
\end{abstract}

Key Words : inundation and drainage processes, urban steep river, urban flooding, numerical simulation

\section{1. はじめに}

1997年の河川法改正において，河川環境の整備と保全 が目的化され，河川整備事業の中で環境機能を考える川 づくりが進められてきた. その一方では，2005年9月の 宮崎豪雨災害のような観測史上最大あるいはそれに近い 規模の集中豪雨の発生が稀ではなくなり，水災が頻発す るようになってきた.

このような自然外力の増大などの自然的状況および限 られた投資余力などの社会的状況の変化を受け，浸水被 害軽減対策が重要になってきている.すなわち，2003年 には「特定都市河川浸水被害対策法」が成立し，2005年 には「水防法」が改正され，浸水想定区域を指定する河 川の範囲の拡大，中小河川における洪水情報の提供の充 実などが新たに定められた。このような法的な整備がな される一方，1994年からはハザードマップの作成が開始
されるとともに，「水防法」の改正を受け，主要な中小 河川でも浸水想定区域の指定が義務づけられるに至って いる．また，2005年4月には「洪水汇濫による被害最小 化を基本とする減災」への転換 ${ }^{1)}$ がこれからのわが国の 治水対策として打ち出されている.

一般に，中小河川は計画規模が小さく，また整備の遅 れも目立っており，治水面で脆弱な状態に置かれている. 特に, 中小都市河川では，2003年7月の九州豪雨災害の ように，氾濫時には一般家屋のみならず，ライフライン 施設，公共交通機関，地下空間施設などの公共施設にま で被害が及ぶことから，流域の特性を踏まえた被害最小 化対策がきわめて重要になる.

以上のように，中小都市河川では河川環境の再生が, その流域では超過洪水時の減災が求められている. 本研 究は, 現在, 段階的に河川再生事業が進められているA 川の河道特性とその流域特性を踏まえた上で，河道整備 
途上での減災対策の一環として, 計画高水に対する浸水 ならびに排水プロセスについて検討を加えたものである.

\section{2. 解析対象領域の概要}

A川は，K市の副都心であるK地区の中心部を貫流し， 支川のM川と合流した後，D湾に注ぐ延長4,165m，流域 面積 $3.6 \mathrm{~km}^{2}$ の掘り込久都市小河川（二級河川，計画規模 1/50) である. 現在，まちづくりの一環として，上流か ら河口までをA，BおよびCの3区間にゾーニングし，区 間毎にテーマ性を持たせた再生事業が計画・実施されて いる.

現況河道の状況としては，A区間とC区間は改修済み 区間であり，これらの中間に位置するB区間が未改修区 間として残っている.未改修区間は市街地中心部にあ たっており, 蛇行部や暗渠部を有し, 流下能力が不足し ている. このため, 計画高水を安全に流下させられる河 道改修案が検討されている.

各区間の河床勾配は，A区間で1/80〜1/40，B区間で 1/300〜1/150およびC区間で1/600〜1/300であり，A区間 からB区間上流にかけて急流河川となっている. 再生事 業により，A区間の流下能力は確保されているが，横断 形状は水際に変化を持たせ，縦断形状は勾配 $1 / 10$ の斜路 と斜路工（射路と減勢工よりなる）と斜路が5箇所に連 続的に設けられた複雑な河道形状となっている. なお, C区間は十分な流下能力を有している.

$\mathrm{A} 川$ 川流域は，丘陵部，平野部および埋立地で構成さ れており，土地利用形態はそれぞれ住宅地，市街地およ び工業地帯にほぼ対応している。市街地は，JRのK駅か ら放射状に延びる大通りを主軸として，網目状に小さな 通りが連なり，H山に向かって扇状に広がっている，標 高はH山から市街地中心部に向かって低くなっており， $\mathrm{JR}$ のK線の主要駅のひとつであるK駅周辺が最も低い. また，東西にはしるJR線路によってK地区中心部は市街 地側と埋立地側とに分断されており，鉄道に沿って主要 交通路（国道）も位置し交通の要となっている.

市街地を貫流するA川が汇濫した場合，市街地中心部 に向かって汇濫水が流れ下ることになるが，線路の盛土 によって埋立地側には流出しにくい構造となっており， 雨水はK駅周辺に湛水する. また， $\mathrm{K}$ 地区の雨水は $\mathrm{A} 川$ と雨水排除システムによって，D湾に排水されるように なっているが，雨水排除に時間を要する場合は，鉄道利 用者や車両交通に支障をきたす可能性がある.

以上のように，A川上流部は複雑な断面形を有する急 流河川, 中流部は蛇行部之暗渠部を有する流下能力が不 足した未改修区間であること，一方，K地区は丘陵地に 発達した密集市街地であり，未改修区間が市街地中心部 にあたっていること，標高が最も低いところに位置する JR線路の盛土によって雨水が市街地側に湛水する地形形
状となっていることなどが河道と流域の特徴である.

\section{3. 氾濫解析}

著者らが開発中の都市域汇濫·浸水対策シミュレー 夕2),3,4) を用い， $\mathrm{A} 川$ 川河道特性と $\mathrm{K}$ 地区の汇濫原特性を 考慮した浸水・排水シミュレーションを実施した. 解析 では，氾濫流量を的確に算定する目的で，河道と汇濫原 を一体的に取り扱う河道・汇濫原包括解析 2 ,3,3,4)を行って いる. 以下に解析目的，解析条件などを示し，境界条件 などの取り扱いについて述べる.

\section{(1) 解析目的}

K地区の流域特性と排水システムを勘案すると，そこ での浸水プロセスと湛水量には，主に(1)A川からの汇濫， (2)A川と雨水排水システムの排水能力，および(3)降雨に よる表層流が関与していると考えられる，そこで，計画 高水に対する現況河道を対象として, Run1（河道から の汇濫）, Run2（河道からの汇濫と雨水排水システム を考慮した解析）およびRun3（河道からの氾濫，雨水 排水システム，および降雨による表層流を考慮した解 析）の3とおりの解析を実施することで，(1)～(3)が浸水 プロセスと湛水量に及ぼす影響について定量的な評価を 試みた。

\section{（2）解析条件}

Run1の解析条件は，以下に示すとおりである，Run2 とRun3では, Run1の解析条件に加え, 内部境界条件と して, Run2では雨水排除システム，Run3では雨水排除 システムと降雨を考慮した.

- 上流端境界条件 : 計画規模に引き伸ばした降雨に基 づく流量ハイドログラフ

- 下流端境界条件 : 朔望平均満潮位

- 内部境界条件 : 支川の流入や雨水幹線からの排水に よる流量の増加

\section{(3) 解析対象領域}

図-1にA川の流域，流域を地形起伏に基づき分割した 小流域と汇濫解析の対象領域をそれぞれ示寸．なお，小 流域 4 はM川の流域である. 汇濫解析の解析範囲は次の ように定めた. すなわち，未改修区間を含む現況河道を 対象として, SA-FUF-2DFモデル5),6,7)を用いた平面 2 次 元不定流解析を実施し，溢水危険箇所を特定した．次に， 図-1の赤枠で示した区間を含むように解析対象領域を設 定した. 平面 2 次元不定流解析の結果から, 計画高水に 対しては，鉄道盛土や $2 \mathrm{~m}$ 以上標高が高い箇所までに氾 濫水は及ばないと推定されたので，A川の上下流につい ては最も上流側の溢水箇所より標高が $2 \mathrm{~m}$ 高い等高線か ら鉄道盛土まで，その他の箇所はA川堤防の地盤高より も標高が $2 \mathrm{~m}$ 以上の箇所までを解析対象領域とした。 な 

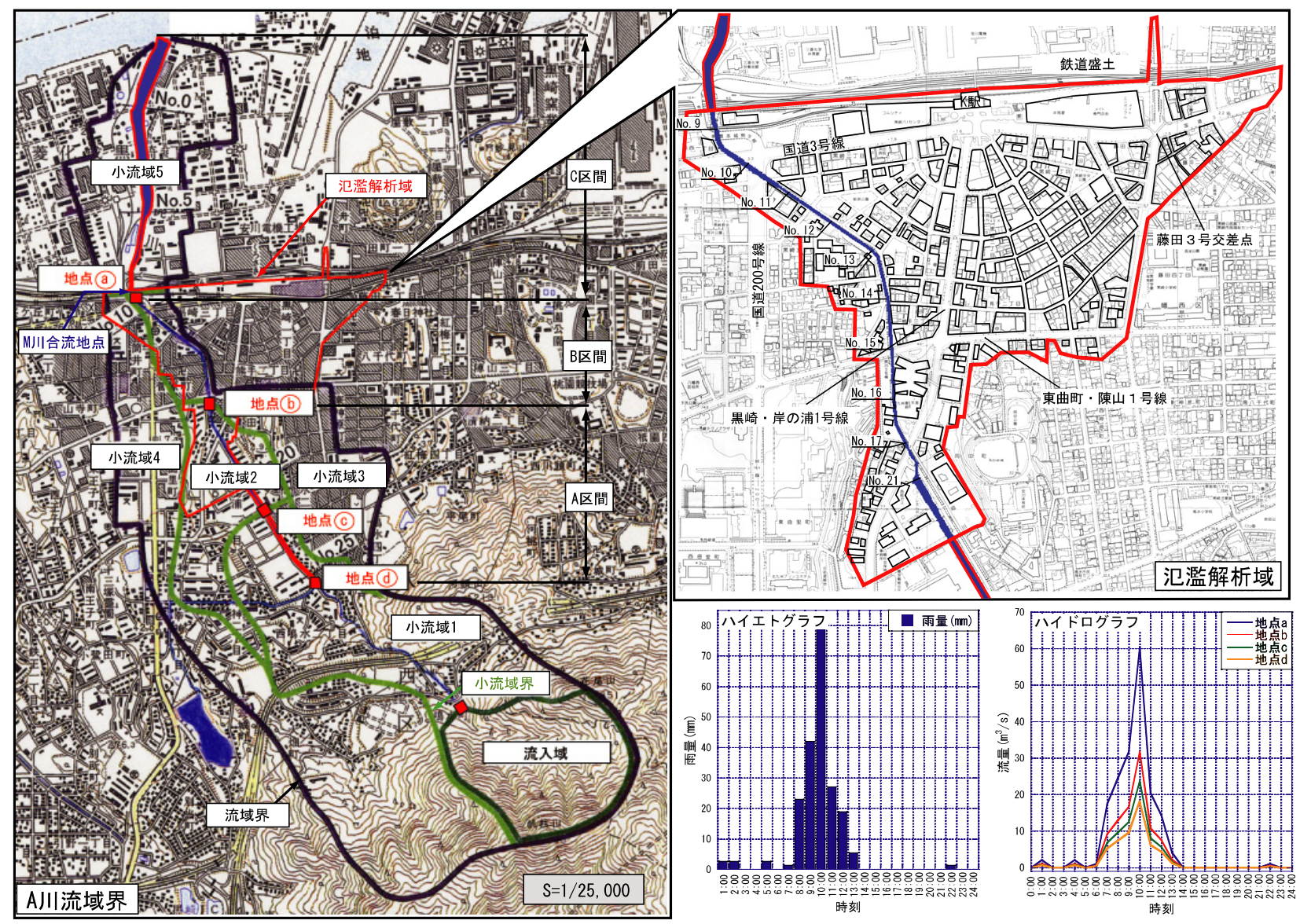

図-1 A川流域における流出解析の流域界

お，図-1中の地点(C)と@，地点(b)および地点@はそれぞ れ小流域1，小流域2および小流域3 上小流域4からA川 の流入点である.

\section{（4）解析条件の詳細と境界条件の取扱い}

【流出解析】：汇濫解析の境界条件として，A川流域 から流出してくる計画雨水相当の流入ハイドログラフを 算出寸る必要がある。ここでは，A川が流域面積 $50 \mathrm{~km}^{2}$ 未満程度で，流量観測值がなく上流に洪水調節施設が存 在しない河川であることから，合成合理式を用いた。

汇濫実績があるハイエトグラフ(図-1)を基準点の計画 降雨量をもとに引伸ばしたハイエトグラフを外力として, 合理式に基づき，図-1に示寸ハイドログラフを算出した なお，引伸ばし率は1.35であり，2以下である.

【河道の上・下流端境界条件】：上流端には合理式に 基づき算出した流量ハイドログラフを，下流端境界条件には 朔望平均満潮位 $(1.0 \mathrm{~m})$ を与えた.

【内部境界条件】：雨水排除システムについては，各 排水区の排水先となる幹線下水道の計画流量または排水 機場の計画排水量 $Q_{d}$ を排水区の面積で除した単位面積 あたりの排水量 $q_{d}$ をそれぞれ求め, 連続の式の消滅項と して各計算メッシュに与え処理した.

降雨については，引伸ばした降雨量に基づき，流出係 数を用いて単位面積当りの流出流量 $q_{r}$ を求め, これを連 続の式の発生項として各計算メッシュに与え処理した.
Run2では雨水排水システムを取扱うために $q_{d}$ を連続の式 で考慮した．なお，雨水排水システムによる排水量は単 位面積当り $1.3 \times 10^{-5}(\mathrm{~m} / \mathrm{s})$ であり，地表面より排水され た雨水が下水道を通り排水されるまでの時間などは考慮 していない. Run3ではK地区の地形特性を踏まえ, 雨水 排水システムで排水できなかった余水を表面流として取 扱うために， $q_{r}$ と $q_{d}$ を連続の式で考慮した．支川の流入 や雨水排水システムからの排水量は，内部境界条件とし て流量の増加分を加え処理した. 排水量は, 図-1に示し た小流域3 と小流域4については地点@一，小流域2につ いては地点(b) 一与えた. M川からの流入は, 流出解析よ り得られたハイドログラフを別途内部境界条件として地 点@に与えた. A川流域には含まれないK駅周辺を含む 領域については, 雨水がD湾に直接排水されるため, 計 算領域外一排出した. 地点〔および地点@については流 出解析より得られたハイドログラフを内部境界条件とし て与えた.

【河道形状 - 粗度係数 - 地盤高 - 構造物の取り扱 い：河道縦断・横断形状は次の要領で設定した. A区 間では，計画河床高と計画断面に，B区間では現況およ び計画縦・横断形状に基づき作成した. C区間では河床 高は現況, 計画縦断形状, 横断形状は既知の断面形状を 基本断面として，その横断面を1/500の地形図から読み 取った川幅に合わせて拡大・縮小し作成した.

K地区の粗度係数 $n$ は, 土地利用形態に応じた值を各 


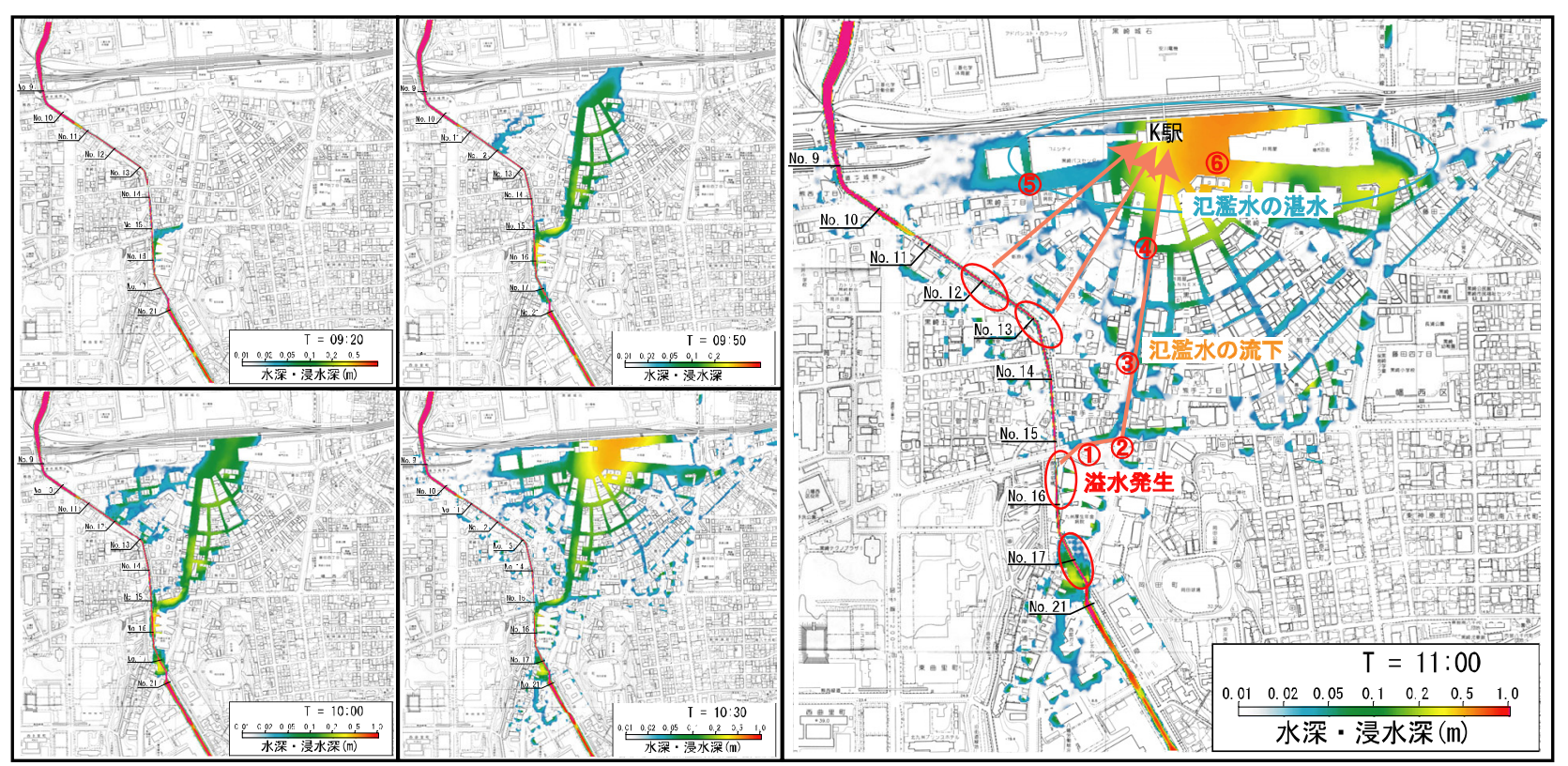

図-2 浸水プロセス

面ごとに設定した．K地区の地盤高は，10mメッシュの 数值地図に1/1,500地形図から読み取った標高点の座標と 地盤高を加え，再度 $10 \mathrm{~m}$ 毎に線形補間し直し設定した。 数值地図は $1 / 25,000$ の地形図から作成されており, 平地 部では数mの誤差を含んでいる。このため, その誤差を 最小化するために1/1,500地形図に基づく補正を行い, $0.1 \mathrm{~m}$ の解像度を有する標高データとした。 また，街区等 の市街地構造は1/1,500地形図に基づき設定した。なお, $\mathrm{K}$ 地区の各街区の建物占有率の平均值は85\%以上であっ たので，各街区を閉境界として取扱い境界に計算セルを 配置した.

\section{4. 解析結果}

\section{（1）浸水プロセス}

図-2にRun3の浸水プロセスを示す。なお， Run1と Run2の浸水プロセスは紙面の都合で割愛する.

眓中に示した時刻は，流量ハイドログラフに対応して いる. Run1では，(1)平面 2 次元解析結果と同様にNo.15 〜No.16の区間から9:10頃に溢水が始まり，(2)汇濫水は 東曲町・陳山1号線加墨崎・岸の浦1号線を図中の実線 で示すように流下し，国道を横切った後，9:50頃にK駅 周辺にまで到達する. (399:50頃には，No.12付近，10:00 にはNo.13付近からも溢水が始まり, 汇濫水が国道一広 がる。.また，No.17付近からも溢水が生じ，汇濫水は周 辺地形の地盤高の関係によりそこで湛水する. (4)10:20 頃にはNo.13付近，10:30頃にはNo.12付近，10:50頃には No.16付近からの溢水が止まる. (5) 11:00には約 $11,300 \mathrm{~m}^{3}$ の汇濫水が市街地中心部のK駅周辺に湛水する.

Run2では, Run1の(1)〜4)までは同様な浸水プロセス となるが，K駅周辺では雨水排水システムで排水された
分だけ湛水域や湛水深が小さくなる。このため，10:30 でのK駅周辺の湛水量はRun1の0.75倍程度 (約8,500 $\mathrm{m}^{3}$ ) となる.

Run3では，Run1の(1)～(3)までは同様な浸水プロセス となる. (4)雨水排水システムで排水できなくなった余水 が，K駅周辺などの地盤高の低い箇所に集まり湛水する. (5)10:30頃にはNo.12とNo.13付近，11:00頃にはNo.16付近 からの溢水が止まる。 また同時刻には約 $18,000 \mathrm{~m}^{3}$ の汇濫 水がK駅周辺に湛水する. 6) その後降雨量が減少し, 雨 水排水システムの排水効果により，氾濫域は時間の経過 とともに減少する.

\section{（2）湛水量の経時変化}

図-3に湛水量の経時変化を示す.

Run1では，排水がないために，溢水の開始とともに 増加した後に湛水量は一定となる. また, 河道付近の汇 濫水が河道内水位の低下により河道へ戻るため, ピーク 值付近で若干減少する，Run2では，10:30にピーク（約 8,500 $\left.\mathrm{m}^{3}\right)$ に達した後に，11:20頃には溢水が止まるため に排水により時間の経過とともに減少する. Run1と比 較すると，ピークは同時刻（10:30）に生じているもの の，Run2の方が $3,000 \mathrm{~m}^{3}$ 程度小さい. すなわち, この時 刻までに雨水排水システムにより $3,000 \mathrm{~m}^{3}$ の氾濫水が排 水されたことになる. 溢水開始からピークが発生するま では80分であり，解析対象領域全体で見れば平均的に $0.625 \mathrm{~m}^{3} / \mathrm{s}$ で排水されたことになる.Run3では，11:00に ピーク (約 $\left.18,000 \mathrm{~m}^{3}\right)$ に達し，降雨量の減少に伴い，雨 水排水により時間の経過とともに減少する.

\section{（3）氾濫流量}

図-4に河道からの汇濫流量を示す.

Run1では，10:05にピークを迎え，No.16の溢水がおさ 


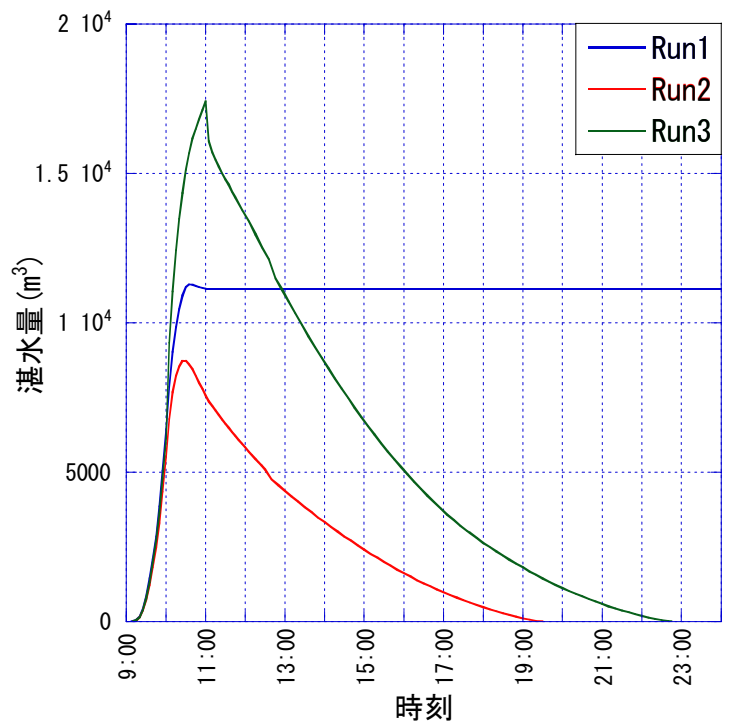

図-3 湛水量の経時変化

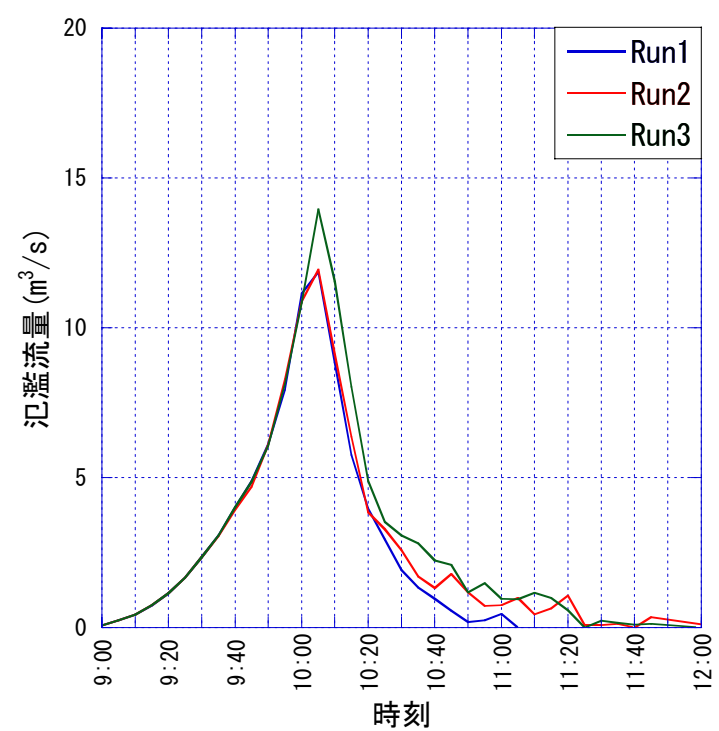

図-4 汇濫流量の経時変化

まる10:50にはほぼ0となるが，11:05に0となる，また， ピーク流量は約 $12.0 \mathrm{~m}^{3} / \mathrm{s}$ である．Run2では，10:05にピー クを迎え，No.16付近からの溢水がおさまる10:50頃には No.17付近で汇濫原と河道との間で $2 \mathrm{~m}^{3} / \mathrm{s}$ 程度の若干の雨 水のやり取りがあった後, 11:20頃で0となる. Run1と比 較すると，10:20以降に若干の違いが生じている。これ は，Run2では雨水排水システムにより汇濫原の水が低 下寸る一方, 排水された汇濫水が河道に流入寸るため, 排水地点下流では河道を流れる流量が増加し, 河道から 溢水しや寸くなったためである. また，ピーク流量は，

Run1 と同じで $12.0 \mathrm{~m}^{3} / \mathrm{s}$ であり, 排水流量の約20倍の氾濫 流量となっている.Run3では，河道からの溢水と表層 流による氾濫流量の和となっている，氾濫流量は10:05 にピークを迎え11:20付近で0となる. また，ピーク流量 は $14.0 \mathrm{~m}^{3} / \mathrm{s}$ 程度であり, Run1 とRun2の約1.2倍となる.

\section{（4）浸水深と流速の経時変化}

図-5と図-6に図-2中の地点(1)〜 (6)における浸水深と流
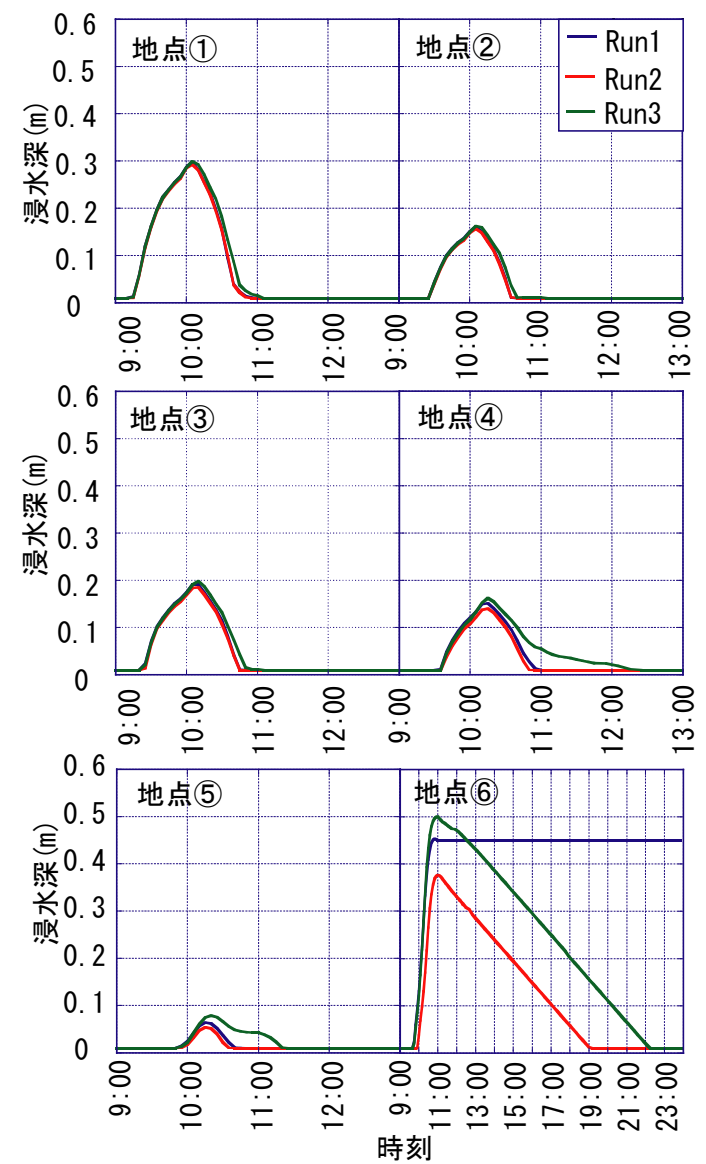

図-5 浸水深の経時変化
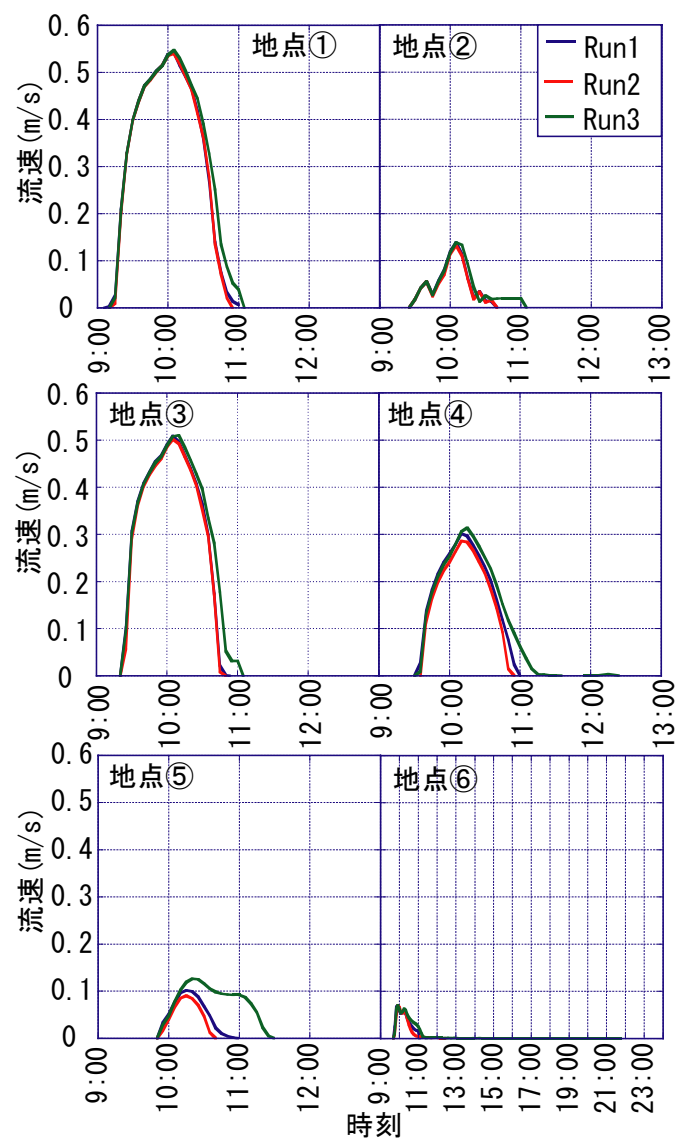

図-6 流速の経時変化 
速の経時変化をそれぞれ示す．

Run1では，浸水深は地点(6)で最大となり，約 $0.45 \mathrm{~m} の$ 湛水深が生じる. 浸水深 $0.5 \mathrm{~m}$ 程度では自動車のエンジン 停止の恐れがあることから，その対策として浸水プロセ スに基づき，交通規制の手順や迂回路を定めるおく必要 がある．流速については，地点(1)で最大となり $0.55 \mathrm{~m} / \mathrm{s}$ 程 度となる. その後, 地点(2)で一旦 $0.12 \mathrm{~m} / \mathrm{s}$ 程度, 地点(4)か ら地点(6)と流下寸るにつれて $0.08 \mathrm{~m} / \mathrm{s}$ 程度となる.

Run2では, 浸水深は地点(6)で最大となり, 約 $0.38 \mathrm{~m} の$ 湛水深が生じる. Run1 と比較すると, 溢水箇所に近い 地点(1)～(3)では有意な違いは認められないが，溢水地点 から遠い地点(4)〜 (6)では違いが生じおり, 特に地点(6)で は湛水深が $0.1 \mathrm{~m}$ 程度小さくなっている，流速については， 雨水排水システムにより浸水深が小さくなる地点(4)～(6) ではRun1に比べ1割程度小さくなるが，地点(1)では最大 (約 $0.55 \mathrm{~m} / \mathrm{s})$ となる.

Run3では，浸水深は地点(6)で最大となり，6時間弱 （10:20～16:00）にわたって約0.3m以上の湛水が生じる. 対策として交通規制や迁回路の設定が必要となる．流速 については, Run2 と同様に地点(1)で最大となり， $0.55 \mathrm{~m} / \mathrm{s}$ 程度となる。地点(1)での浸水深はRun1, Run2 と 同様であり, 歩行困難度も同様である。その後は, 10:00まではRun1やRun2と同様な挙動を示すが，それ以 降は降雨の影響により, Run1 とRun2とは異なってくる 特に, 雨水が湛水する地盤高の低い (4)〜 (6)については有 意な差異が認められ，浸水深は大きくなる．また，流速 についても浸水深と同様にRun3は他のRunに比べ大きく なる.

\section{5. 結論}

氾濫・浸水対策検討シミュレータを用いたシミュレー ションにより以下のような知見を得た.

（1）計画降雨時の河道からの汇濫流量（Run1）と雨水 排水システムを考慮した場合の氾濫流量（Run2） は同程度 $\left(\right.$ 約 $\left.11,300 \mathrm{~m}^{3}\right)$ となる. 降雨と雨水排水 システムを考慮した場合の河道からの汇濫流量

（Run3）は，河道境界での表層流の流量も加わる ことで，Run2の1.2倍程度となる.

（2）Run1，Run2およびRun3での最大湛水量は，それぞ れ $11,300 \mathrm{~m}^{3} ， 8,500 \mathrm{~m}^{3}$ および $18,000 \mathrm{~m}^{3}$ 程度となる。

Run1の湛水量はRun2の湛水量より $3,000 \mathrm{~m}^{3}$ 程度大き い一方で，汇濫流量には違いがない。このことか ら, 雨水排水システムにより $3,000 \mathrm{~m}^{3}$ 程度の氾濫水 が排水されると予想される。. また，Run3の湛水量 は，降雨による雨水排水システムの排水不良と $\mathrm{A} 川$ からの氾濫流量の15\%程度の増加により, Run2よ
り約 $10,000 \mathrm{~m}^{3}$ 大きくなる.これより, 湛水量に占 める余水の量は $10,000 \mathrm{~m}^{3}$ 程度であると予想され， この量はA川からの全汇濫流量に匹敵している. B 地区のような地形特性を有する都市部では湛水量 が余水に大きく左右されることを示している.

（3）いずれのRunにおいても，浸水プロセスはほぼ同様 であり，K駅周辺に湛水する. 雨水排水システムに よりRun2では河道からの汇濫水が約8時間，Run3 では河道からの汇濫水と余水が約 11 時間で排水さ れる. 歩行困難度については, 解析対象領域の地 形特性から流速が速いところでは水深が浅く, 逆 に湛水深が大きなところでは流速が遅くなるため 特に問題とはならない，ただし，K駅周辺では6時 間弱にわたって約 $0.3 \mathrm{~m}$ 以上の湛水が生じることか ら，鉄道利用者に向けた対応が必要である。一方， 車両交通については, 浸水深は主要交通路である 国道で車の通行が困難となる水深 $0.3 \mathrm{~m}$ をRun2では 約2時間, Run3では約6時間越え, 通行困難が予想 される，その対策として交通規制や迂回路を検討 しておく必要がある.

謝辞 : 本研究は，K市との共同研究として実施したもの である．また，本研究の一部は，科学研究費補助金 基 盤研究B (課題番号 : 17360237, 研究代表者 : 秋山壽一 郎）の助成を受けた.ここに記して謝意を表します。

\section{参考文献}

1) 豪雨災害対策総合政策委員会 : 総合的な豪雨災害対策の推進 について, 社会資本整備審議会河川分科会, 2005年.

2) 秋山壽一郎・重枝末玲 : 飯塚市を中心とした都市域のダイナ ミック汇濫解析 -2003 年7月遠賀川豪雨災害を対象として-, 水工学論文集, 第49巻, pp. 619-624, 2005.

3) 秋山壽一郎・重枝末玲 : 河道特性と市街地構造を考慮した越 水・破堤汇濫シミュレーション, 水工学論文集, 第 50 巻, pp. 691-696, 2005.

4) 秋山壽一郎・重枝末玲 : 河道・氾濫域包括解析による汇濫流 量の評価と市街地破堤汇濫解析，土木学会論文集（投稿中）, 2006.

5) 秋山壽一郎・重枝末玲・浦 勝 : 非構造格子を用いた有限体 積法に基づく1次および2次精度平面2次元洪水流数值モデル， 土木学会論文集, No. 705/II-59, pp. 31-43, 2002.

6) 重枝未玲・秋山壽一郎 : 市街地構造を考慮した氾濫解析モデ ルの総合的な検証，水工学論文集，第48巻，pp. 577-582, 2004.

7) 秋山壽一郎・重枝末玲-鬼束幸樹 - 白川寬樹 : 平面 2 次元数 值モデルによる急流都市河川の流況解析，水工学論文集，第 48巻, pp. 631-636, 2004.

(2006. 9. 30受付) 